\title{
БІОЛОГІЧНИЙ ВІК ТА ТЕМПИ СТАРІННЯ СТУДЕНТІВ
}

Львівський національний медичний університет імені Данила Галицького

Резюме. Вивчалися біологічний вік, темпи старіння і стан здоров'я студентів Львівського національного медичного університету імені Данила Галицького за допомогою методу В.П. Войтенка. Розбіжності між календарним і біологічним віком дали змогу оцінити інтенсивність старіння і функціональні можливості досліджуваних осіб. У результаті обчислень з'ясовано, що в переважної більшості обстежуваних, які ігнорували здоровий спосіб життя і мали низький рівень рухової активності, показник фактичного біологічного віку

Вступ. Аналіз тривалості життя українців показує, що останнім часом цей показник, загалом як і стан здоров'я населення всіх вікових груп, досягає критично низьких рівнів [6]. Усі дослідники звертають увагу на передчасне старіння організму, темпи якого можна визначити, оцінюючи біологічний вік $[1,4,9]$. Думки авторів, котрі досліджують проблему передчасного старіння людини, сходяться на визначенні поняття «біологічний вік» як загальної психофізичної дієздатності (повносправності) і життєздатності організму, що визначається на підставі біологічних тестів, через порівняння з визначеними параметрами, властивими для цього віку $[1,4,7,9,10]$.

Біологічний вік дозволяе оцінити ступінь відповідності біологічного стану організму календарному віку людини, відображає темпи розвитку та біологічного старіння, від яких залежить функціонування основних систем життєзабезпечення та тривалість життя. Розбіжності між календарним і біологічним віком дають змогу оцінити інтенсивність старіння і функціональні можливості індивіда $[1,3,7]$.

Загальновідомо, що фізичний стан осіб молодого віку, зокрема студентів, протягом останнього десятиріччя різко погіршився внаслідок поглиблення соціально-економічної, екологічної та демографічної криз $[6,8,9]$.

Також, незважаючи на наявність методики оцінки біологічного віку, проблема біологічного віку і передчасного старіння молоді студентського віку вивчена недостатньо [5, 6, 8, 9, 10, 11].

Мета дослідження. Визначити фактичний біологічний вік та оцінити темпи старіння і стан здоров'я студентів III курсу Львівського національного медичного університету імені Данила Галицького.

Матеріал і методи. У дослідженні взяли участь 86 студентів 3-го курсу стоматологічного факультету ЛНМУ імені Д. Галицького, яким на момент обстеження виповнилося 19 років. Серед обстежуваних було 24 хлопці і 62 дівчини. Досліджувані ігнорували здоровий спосіб життя і мали низький рівень рухової активності. До методів (С) 3.Р. Леонт'єва, Р.Я. Дутка, 2016 перевищував значення належного біологічного віку, для них були характерні прискорені темпи старіння $\mathrm{i}$ поганий стан здоров'я. Розроблені відповідні рекомендації щодо скорочення невідповідності між належним, фактичним та календарним біологічним віком у студентів, які включали в себе відмову від шкідливих звичок, підвищення рухової активності, заняття оздоровчим бігом та плаванням.

Ключові слова: біологічний вік, темпи старіння, здоров'я студентів.

обстеження належали: аналіз джерел літератури, визначення біологічного віку людини методом В.П. Войтенка (анкетування, антропометрія, проба Штанге, проба Генчі, проба Озерецького), методи математичної статистики.

Методика визначення біологічного віку та темпів старіння (В.П. Войтенко, 1991 р.) [2, 3] включала наступні етапи:

1. Розрахунок дійсного значення біологічного віку обстежуваного (за набором клінікофізіологічних показників).

2. Розрахунок належного значення біологічного віку за допомогою календарного віку.

3. Зіставлення фактичної (дійсної) і належної величин біологічного віку. Оцінка різниці між ними дозволяє встановити на скільки років обстежуваний випереджає чи відстає від однолітків за темпами старіння.

Для розрахунку фактичного біологічного віку (ФБВ) використовували наступні формули:

Чоловіки: ФБВ $=44,3+0,68 \times \mathrm{CO} 3+0,40 \times$ АТс $-0,22 \times$ АТд - 0,22 $\times$ ПАТ - 0,004 $\times$ ЖЕЛ $0,11 \times 3$ ЗВд + 0,08 × ЗДВид - 0,13 × СБ;

Жінки: ФБВ $=17,4+0,82 \times \mathrm{CO} 3-0,005 \times$ АТс $+0,16 \times$ АТд $+0,35 \times$ ПАТ $-0,004 \times$ ЖЕЛ + $0,04 \times$ ЗДВд - 0,06 × ЗДВид - 0,11 × СБ, де АТс та АТд - артеріальний тиск систолічний і діастолічний, які вимірювали методом Короткова за допомогою тонометра на правій руці, в положенні сидячи, тричі з інтервалом у 5 хвилин. Враховували найменший результат. На підставі різниці між АТс та АТд визначали пульсовий артеріальний тиск (ПАТ).

Життєва ємність легень (ЖЕЛ) вимірювалась у положенні сидячи спірометром будь-якого типу, не менш ніж через 2 години після прийому їжі.

Час затримки дихання після глибокого вдиху (ЗДВд) - проба Штанге та глибокого видиху (ЗДВид) - проба Генчі - вимірювалися тричі з інтервалом через 5 хвилин за допомогою секундоміра. Обиралась найбільша величина обох показників.

Статичне балансування (СБ) (проба Озерецького) - вимірювалось у положенні стоячи досліджуваного на лівій нозі, очі закриті, руки опуще- 
ні вздовж тулуба, без попереднього тренування. Враховувався найкращий результат із трьох спроб з інтервалами між ними в 5 хвилин.

Календарний вік (КВ) - число прожитих повних років.

Індекс самооцінки здоров'я (CO3) - визначався за спеціальною анкетою, яка передбачала відповіді на 29 запитань.

Для розрахунку належного біологічного віку (НБВ) застосовувались формули:

$\mathrm{HБВ} \mathrm{(чол.)}=0,661 \times \mathrm{KB}+16,9$;

НБВ (жін.) $=0,629 \times$ КВ $+15,3$, де КВ- календарний вік у роках.

Результати дослідження та їх обговорення. В обстежуваних було вирахувано НБВ, який становив для дівчат - 25-27 років, а для хлопців 29-46 років.

При обчисленні ФБВ встановлено, що практично у всіх хлопців і вбільшості дівчат він перевищував показники НБВ. Дані щодо цього питання представлені у таблиці 1 .

У всіх обстежуваних ФБВ перевищував КВ, що відображено у таблиці 2.
3 таблиць 1 і 2 видно, що нижчі, більш наближені до НБВ показники ФБВ мали дівчата, що може бути пов'язаним, у свою чергу, більш шанобливим ставленням серед них до свого здоров'я на противагу хлопцям.

На підставі різниці між показниками ФБВ та НБВ визначалися: функціональний клас (ФК), темпи старіння та рівень здоров'я студентів (за методом В.П. Войтенка, 1991р.) (табл. 3).

Таким чином, при порівнянні показників ФБВ з КВ встановлено, що в 16,66 \% хлопців і $62,90 \%$ дівчат фактичний біологічний вік перевищував календарний до $100 \%$, у 33,34 \% хлопців і 33,87 \% дівчат - до $150 \%$ і в 50,50\% хлопців i 3,23\% дівчат - від 150 до $200 \%$. Щодо темпів старіння та стану здоров'я визначено наступне: у 4,17 \% хлопців і 9,68 \% дівчат, які були віднесені до II ФК (за методом В.П. Войтенка) стан здоров'я був добрий, темпи старіння - уповільнені, у $4,17 \%$ хлопців і 24,19\% дівчат (III ФК) стан здоров'я був середній, а темпи старіння не відрізнялися від популяційного стандарту, для 12,50\% хлопців і 25,81\% дівчат (IV ФК) були характерні прискорені темпи старіння і поганий стан здоро-

Таблиця 1

Розподіл вирахуваних показників фактичного біологічного віку в досліджуваних студентів обох статей

\begin{tabular}{|c|c|c|c|c|}
\hline & ФБВ (від 20,0-до & ФБВ (від 30,0-до & ФБВ (від 40,0-до \\
49,9 рp.) & $39,9$ pp. $)$ & $\begin{array}{c}\text { ФБВ (від 50,0 і біль- } \\
\text { ше) }\end{array}$ \\
\hline Хлопці $(\mathrm{n}=24)$ & $1 \mathrm{oc}$. & 4 ос. & 14 ос. & 5 ос. \\
\hline Дівчата $(\mathrm{n}=62)$ & 13 ос. & 35 ос. & 12 ос. & 2 ос. \\
\hline
\end{tabular}

Примітка. n - кількість осіб; ФБВ - фактичний біологічний вік; ос. - особа, осіб

Таблиця 2

Ступінь перевищення показників фактичного біологічного віку над календарним віком

\begin{tabular}{|c|c|c|}
\hline \multirow{2}{*}{ Величина перевищення у $\%$} & \multicolumn{2}{|c|}{ Кількість студентів у \% } \\
\cline { 2 - 3 } & Хлопці & Дівчата \\
\hline До $100 \%$ (у 2 рази) & $16,66 \%$ & $62,90 \%$ \\
\hline Від 101 до $150 \%$ ( у 2-2,5 раза) & $33,34 \%$ & $33,87 \%$ \\
\hline Від 151 до $200 \%$ (у 2,5-3 рази) & $50,50 \%$ & $3,23 \%$ \\
\hline
\end{tabular}

Таблиця 3

Оцінка функціонального класу, темпів старіння та рівнів здоров'я обстежуваних студентів

\begin{tabular}{|c|c|c|c|c|}
\hline \multirow{2}{*}{$\begin{array}{c}\text { Функціона- } \\
\text { льний клас }\end{array}$} & $\begin{array}{c}\text { Відхилення біологіч- } \\
\text { ного віку від популя- } \\
\text { ційного стандарту }\end{array}$ & Темпи старіння та стан здоров'я & \multicolumn{2}{|c|}{ Кількість обстежуваних } \\
\cline { 3 - 5 } & $-9,9$ і менше & $\begin{array}{c}\text { Темпи старіння різко уповільнені, } \\
\text { стан здоров'я дуже добрий }\end{array}$ & - & Дівчата \\
\hline I & $-8,9$ до - 3 & $\begin{array}{c}\text { Темпи старіння уповільнені, стан } \\
\text { здоров'я добрий }\end{array}$ & $1(4,17 \%)$ & $6(9,68 \%)$ \\
\hline II & $-2,9$ до $+2,9$ & $\begin{array}{c}\text { Темпи старіння не відрізняються від } \\
\text { популяційного стандарту, стан здо- } \\
\text { ров'я середній }\end{array}$ & $1(4,17 \%)$ & $15(24,19 \%)$ \\
\hline III & +3 до +8,9 & $\begin{array}{c}\text { Темпи старіння прискорені, стан } \\
\text { здоров'я поганий }\end{array}$ & $3(12,50 \%)$ & $16(25,81 \%)$ \\
\hline IV & +9 і більше & $\begin{array}{c}\text { Темпи старіння дуже прискорені, } \\
\text { стан здоров'я поганий }\end{array}$ & $19(79,16 \%)$ & $25(40,32 \%)$ \\
\hline V & \multicolumn{2}{|c|}{}
\end{tabular}


в'я, а в 79,16 \% хлопців і 40,32 \% дівчат (V ФК) були дуже прискорені темпи старіння.

\section{Висновки}

1. При обчисленні фактичного біологічного віку в обстежуваних студентів встановлено, що практично у всіх хлопців і в більшості дівчат він перевищував показники належного біологічного віку.

2. Для більшості студентів характерні прискорені темпи старіння і поганий стан здоров'я.

3. Студентам, у першу чергу, порекомендовано відмовитися від шкідливих звичок, намагатися підвищити свою рухову активність, зайнятися оздоровчим бігом, плаванням.

Перспективи подалыших досліджень. У подальших дослідженнях ми плануємо провести аналіз факторів, які впливають на біологічний вік з метою створення комплексного підходу до занять фізичним вихованням та спортом для покращення здоров’я студентів і зниження темпів їх старіння.

\section{Література}

1. Ахаладзе М.Г. Оцінка темпу старіння, стану здоров'я й життездатності людини на основі визначення біологічного віку: автореф. дис. на здобуття наук. ступеня д-ра мед. наук: спец. 14.03.03. «Нормальна фізіологія» / М.Г. Ахаладзе. - К., 2005. - 43 с.

2. Войтенко В.П. Здоровье здоровых / В.П. Войтенко. М.: Здоров'я, 1991. - 248 с.

3. Войтенко В.П. Методика определения биологического возраста / В.П. Войтенко, А.В. Токарь, Э.С. Рудая // Вопр. геронтол. -1989 . - № 11. - С. 9-16.
4. Деев А.И. Проблемиы определения темпа старения человека / А.И. Деев, Е. В. Бухарова // Пробл. старения и долголетия. - 2009. - № 1. - С. 8-19.

5. Коханець П.П. Взаємозв'язки показників фізичного розвитку, функціональної підготовленості і психофізіологічних характеристик студентів-футзалістів 1-го і 2-го курсів / П.П. Коханець // Педагогіка, психологія та медико-біологічні проблеми фізичного виховання $\mathrm{i}$ спорту. - 2010. - № 1. - С. 74-78.

6. Лошицька T.І. Біологічний вік та темпи старіння організму студентів / T.I. Лошицька // Педагогіка, психологія та медико-біологічні проблеми фізичного виховання і спорту. -2010 . - № 7. - С. 50-52.

7. Маркина Л.Д. Определение биологического возраста человека методом В.П. Войтенко: учеб. пособие для самостоятельной работы студ.-медиков и психологов / Л.Д. Маркина. - Владивосток, 2001. - 29 с.

8. Оцінка стану соматичного та психічного здоров'я студентів вищих учбових закладів при адаптації до учбового процесу / М.С. Гончаренко, В.Г. Пасинок, В.Е. Новікова [та ін.] // Педагогіка, психологія та медико-біологічні проблеми фізичного виховання і спорту. - Харків: ХХПІ. - 2006. - С. 12-15.

9. Приходько С.I. Порівняльний аналіз біологічного віку юнаків і дівчат студентського віку / С.I. Приходько // Педагогіка, психологія та медико-біологічні проблеми фізичного виховання і спорту. - 2012. - № 6. C. 104-106.

10. Фединяк Н.Б. Біологічний вік і темп старіння людей різних вікових груп / Н. Фединяк, Б. Мицкан // Молодіж. наук. вісник: Фіз. виховання і спорт. - 2013. Вип. 12. - С. 45-50.

11. Akhaladze N. Biological Age for Assesssing Efficacy of Health Strengthening / N. Akhaladze // Gerontology. 2001. - S. 1, № 47. - P. 286.

\section{БИОЛОГИЧЕСКИЙ ВОЗРАСТ И ТЕМПЫ СТАРЕНИЯ СТУДЕНТОВ}

\section{3.Р. Леонтьева, Р.Я. Дутка}

Резюме. Изучались биологический возраст, темпы старения и состояние здоровья студентов Львовского национального медицинского университета имени Данила Галицкого с помощью метода В.П. Войтенко. Разница между календарным и биологическим возрастом дала возможность оценить интенсивность старения и функциональные возможности исследуемых особей. В результате исчислений выяснено, что у большинства исследуемых, которые игнорировали здоровый способ жизни и имели низкий уровень двигательной активности, показатель фактического биологического возраста превышал значение надлежащего биологического возраста, для них характерны ускоренные темпы старения и плохое состояние здоровья. Разроботаны определенные рекомендации относительно сокращения несоответствия между надлежащим, фактическим и календарным биологическим возрастом у студентов, которые включали в себя отказ от вредных привычек, повышение двигательной активности, занятия оздоровительным бегом и плаванием.

Ключевые слова: биологический возраст, темпы старения, здоровье студентов.

\section{BIOLOGICAL AGE AND THE RATES OF AGING OF STUDENTS}

\section{S.R. Leontyeva, R.Ya. Dutka}

Abstract. The rates of aging, biological age and the health state of the students of Danylo Halytsky Lviv Medical University have been studied according to Voitenko's method. The difference between the calendar and biological ages gave a possibility to evaluate the intensiveness of aging and functional abilities of those under investigation. As a result of calculations it has been determined that in vast majority of the examined who ignored healthy lifestyle and had a low level of physical activity the index of factual biological age exceeded the index of the actual biological one. Those individuals were characterized by the exceeded rates of aging and poor health. Appropriate recommendations have been developed as to the shortage of discrepancy between actual, factual and calendar biological ages of the students, which also required a denial from bad habits, increased physical activity, jogging and swimming.

Key words: biological age, rates of aging, health of students.

Danylo Halytsky National Medical University (Lviv) 